\title{
Letters and the Topography of Early Christianity*
}

\author{
Judith M. Lieu \\ jml68@cam.ac.uk
}

\begin{abstract}
While embedded in contemporary letter-writing conventions, early Christian letters also were instrumental in the creation of a distinctive Christian worldview. Fundamental to letters of all types, 'real' and fictional, is that they respond to, and hence negotiate and seek to overcome, actual and imagined spatial and temporal distance between author and recipient. In practice and as cultural symbols letters, sent and transmitted in new contexts, as well as letter collections, produced in the Christian imagination new trans-locational and cross-temporal dynamics of relationality that can be mapped onto the standard epistolary topoi - 'absent as if present', half a conversation, a mirror of the soul.
\end{abstract}

Keywords

Early Christian letters; epistolography; space; Christian world-view; prosopopoiea; community and individuality.

This paper is given at the $70^{\text {th }}$ meeting of the Society, and although it is neither its $70^{\text {th }}$ year nor its $70^{\text {th }}$ anniversary, it still seemed appropriate to find a suitable scriptural precedent for this presidential lecture. ${ }^{1}$ My 'text', therefore, is the letter that Jeremiah sends to the exiles in Babylon in which he encourages them to shape an identity for themselves as a minority people by maintaining their pattern of productivity, social life and faithfulness for 70 years (Jer. 29 [36]). This letter duly generated a rich trajectory of imitation in letters associated with Jeremiah and his scribe Baruch, while the number seventy itself also became the subject of exegesis and of re-interpretation (cf. Dan. 9.2).2

The theme of this paper is 'the letter'. In recent years it has generally been the Gospel, or the plurality of Gospels, that have served as the primary focus in

\footnotetext{
${ }^{*}$ Presidential address given on $29^{\text {th }}$ July 2015 at the $70^{\text {th }}$ General Meeting of the SNTS in Amsterdam.

1 The first meeting was held in 1947, but two meetings were held in 1952, in Bern in April (the $6^{\text {th }}$ ) and in Durham in September (the $7^{\text {th }}$ ). However, the SNTS traces its foundation to a meeting of scholars called by Johannes de Zwaan in 1938, whose plans for a General Meeting under his presidency for September 1939 were interrupted by the outbreak of war. See G. H. Boobyer, 'The Early History of Studiorum Novi Testamenti Societas', Bulletin of Studiorum Novi Testamenti Societas 1 (1950) 7-10; Lukas Bormann, “'Auch unter politischen Gesichtspunkten sehr sorgfältig ausgewählt": Die ersten deutschen Mitglieder der Studiorum Novi Testamenti Societas (SNTS) 1937-1946', NTS 58 (2012) 41652 .

2 See Lutz Doering, Ancient Jewish Letters and the Beginnings of Christian Epistolography (WUNT 298; Tübingen: Mohr Siebeck) 104-08, 154-60, 190-4, 241-62.
} 
attempts to articulate and to answer some of the central questions regarding the first two centuries that demand critical attention: the dynamic tensions between the oral and the written; creative author and literary reworking; local and global; private and public; history and faith; context and continual re-reception; intention and interpretation; the path to an exclusive canon and the rediscovery of multiformity, and so on. It is certainly not the case that letters have been ignored, and there has been a new wave of reflection on the letter-form as an intrinsic part of Pauline theology and not just as the medium for it. ${ }^{3}$ Indeed, New Testament scholars have made significant contributions to the more general study of letters in antiquity. ${ }^{4}$ However, this paper will not focus on specific letters, nor on the standard prolegomena regarding the practicalities and categories of letter writing, which have been well-documented in works such as these, but on the role of the letter as a cultural symbol.

Through its history, from the ancient world to contemporary reinventions in email and social media, letter-writing has served as a significant cultural symbol in two distinct ways: it has acted, first, as a symbol of how a variety of relationships within society are structured and managed; and secondly, as a symbol of more general practices and understandings of writing and of reception. Like any effective symbol, letter-writing has also embodied and furthered these practices. Alongside so-called 'real' letters, the widespread practice of using letters within or as a form of 'fictional narrative' similarly betray the significance of their cultural associations. ${ }^{5}$ It is not surprising, then, that at particular points, the letter can also be a powerful symbol of the emergence of new patterns of relationship, and of new practices, emerging within an established framework.

Early Christianity has been seen as characterised in particular by its literary creativity and productivity, although this creativity has to be set within the social and literary inventiveness of the contemporary Greco-Roman and perhaps also Jewish contexts. The letter exemplifies this in particular: more, one might suggest, than does the Gospel, the letter gives expression to and it helps bring about the way of being, or of perception, the symbolic universe, the Weltanschauung, the habitus, the identity - chose which ever model most appeals to you - that for convenience we may refer to as 'early Christianity'. There is good historical justification for this claim; the earliest Christian document is surely a letter, arguably 1 Thessalonians, and the formation of a collection of Pauline letters, whatever that first collection or collections may

${ }^{3}$ François Vouga, 'Der Brief als Form der apostolischen Autorität', in Klaus Berger, François Vouga, Michael Wolter, Dieter Zeller, eds., Studien und Texte zur Form-geschichte (Tübingen: Francke, 1992) 7-50.

${ }^{4}$ Hans-Josef Klauck, Ancient Letters and the New Testament: A Guide to Context and Exegesis (Daniel P. Bailey, trsl. and ed., Waco, TX: Baylor, 2006); Abraham J. Malherbe, Ancient Epistolary Theorists (Atlanta, GA: Scholars Press, 1988); Stanley K. Stowers, Letter Writing in Greco-Roman Antiquity (Philadelphia, PA: Westminster, 1986).

${ }^{5}$ Patricia A. Rosenmeyer, Ancient Epistolary Fictions: The Letter in Greek Literature (Cambridge: Cambridge University Press, 2001). 
have contained, perhaps helped provoke imitation both by those claiming the Pauline name and by others appealing to alternative apostolic authority. ${ }^{6}$ It has been proposed that the codex was adopted because of its usefulness for such an epistolary collection, and it also arguable that it was the very notion of collection that formed the nucleus of an ever-expanding apostolic (or 'canonical') witness. ${ }^{7}$ From the third century, letters between bishops became essential mechanisms in the negotiation of authority and patterns of allegiance, while in the fourth and fifth centuries letter-writing reached a high point among Christian leaders. ${ }^{8}$ Even then, however different their voluminous and lengthy correspondence may look, some still saw themselves as heirs of Paul, even when they modelled themselves on Cicero or Pliny: Ambrose both alludes to and cites Paul ('absens erat corpore, sed praesens spiritus'), even while describing the letter in terms of the classical tropes, and perhaps arranging them for publication following earlier classical models (Epist. 37). ${ }^{9}$

However, it is not the historical trajectory but the letter as symbol that is our main concern here. This paper shall engage in a conversation between epistolary theory in antiquity and the contours of what has just been abbreviated as 'early Christianity'. This is, then, itself an exercise in theory, an abstraction painted in broad brush-strokes, although rooted in actual epistolary rhetoric and inviting further application.

Of the various social models for conceptualising 'early Christianity' mentioned above, that of symbolic universe is most pertinent here, because it is a spatial metaphor - this is the 'topography' of the title. Letters instantiate space; they lay claim to space and they shape it; they provide fixed points, boundaries for space; they seek to control it. In what follows three of the cardinal principles of

${ }^{6}$ There is a vigorous bibliography; for the issues see Andreas Lindemann, 'Die Sammlung der Paulusbriefe im 1. und 2. Jahrhundert', in J. M. Auwers \& H. J. de Jonge, eds., The Biblical Canons (BETL 163; Leuven: Peeters/ Leuven University Press, 2003) 321-51.

${ }^{7}$ See Harry Y. Gamble, Books and Readers in the Early Church: A History of Early Christian Texts (New Haven, CT: Yale University Press, 1995) 58-65.

${ }^{8}$ For the importance of letters in third century episcopal politics see Eva Baumkamp, Kommunikation in der Kirche des 3. Jahrhunderts: Bischöfe und Gemeinden zwischen Konflikt und Konsens im Imperium Romanum (STAC 92; Tübingen: Mohr Siebeck, 2014), especially 1-10, 36-46. For the later period see the relevant contributions in Bronwen Neil and Pauline Allen, eds., Collecting Early Christian Letters: From the Apostle Paul to Late Antiquity (Cambridge: Cambridge University Press, 2015). There is a growing bibliography of individual studies which also address the function of these letters as published collections: e.g. Andrew Cain, The Letters of Jerome: Asceticism, Biblical Exegesis, and the Construction of Christian Authority in Late Antiquity (Oxford: Oxford University Press, 2009); Catherine Conybeare, Paulinus Noster: Self and Symbol in the Letters of Paulinus of Nola (Oxford: Oxford University Press, 2000).

${ }^{9}$ See also Jennifer V. Ebbeler, Disciplining Christians: Correction and Community in Augustine's Letters (Oxford: Oxford University Press, 2012) 20-25, 43-56, on Augustine. 
epistolary theory, each of which is ultimately spatial in character, will provide a template against which to explore how early Christian letters exploit those principles in the construction of a new way of ordering experience and reality. These 'spaces' are as much, if not more, metaphorical than locational, and so, inevitably, they overlap each other.

\section{Absent as if present: Geographical distance}

'A conversation from one who is absent to one who is absent ... one will speak in it as if present to one who is present' (Ps.Libanius, Epist. Charact. 2). ${ }^{10}$

Nearly everything else that is to be said about letters - not only in the ancient world - follows from their role as an attempt to overcome physical distance. The trope 'as if present' is a familiar and widespread one. 'As if works in two opposing directions, for if the letter seeks to make writer and recipient present to each other, it also acts as a reminder of the actual fact of absence and in this way reinforces the experience of that absence. The use Paul makes of this theme has been much studied, together with its counterpart, the so-called 'Apostolic Parousia'.11 So too has been the response of the recipients of his letters: 'His letters are weighty and forceful, his physical presence weak and his speech insignificant' (2 Cor. $10.10-11) .{ }^{12}$

This might suggest, then, that absence and presence to some extent can be mapped on to the written and the spoken; yet immediately, any potential opposition between these modes is illusory, for the letter was intended to be read out — the greeting recalling the 'Thus says' spoken by the messenger and so it favoured a more colloquial style. ${ }^{13}$ The letter moves from the oral to the written, and back to the oral, and hence it serves as a paradigm of the movement of texts more generally. Even so, the words that are spoken and heard face-toface are more quickly lost, although they are also more quickly explained. Conversely, as Paul's troubled relations with Corinth again display, writing may appear to be fixed, but the letter-writer loses control of what s/he has written, letting it fall prey to misunderstanding, no longer able to nuance and to reexplain, except by the interchange of yet more letters. Geographical distance, then, makes the recipient(s) an integral element in the production of the letter as well as in its interpretation. An elision between distance in space and distance in

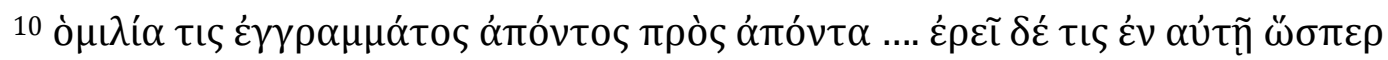

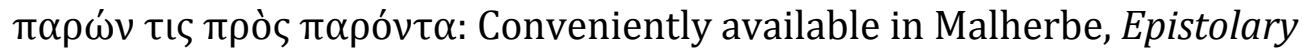
Theorists, 66-81.

${ }^{11}$ Robert W. Funk, 'The Apostolic Parousia: Form and Significance', in W. R. Farmer, C. F. D. Moule, and R. R. Niebuhr, eds., Christian History and Interpretation: Studies Presented to John Knox (Cambridge: Cambridge University Press, 1967) 249-68; also Margaret M. Mitchell, 'New Testament Envoys in the Context of Greco-Roman Diplomatic and Epistolary Conventions: The Examples of Timothy and Titus', JBL 111 (1992) 641-62.

12 For this in relation to contemporary norms see also Jennifer Larson, 'Paul's Masculinity', JBL 123 (2004) 85-97.

13 Thus Ps.Libanius uses the term ò $\mu \iota \lambda i ́ \alpha$; see Demetrius, De Eloc. 223-5 and below p. 000.
} 
time is already evident in Ephesians and it becomes fundamental in the future reception of all letters. ${ }^{14}$ This is in part why subsequent generations, who are separated also by the distance of time, can read letters in a way that they could not join a face-to-face conversation. It follows that the necessary role of the reader is hermeneutically implicit in the epistolary genre.

Letters mark the space between sender and recipient, and in one sense they also fill that space. This is true both physically and in the imagination. In practical terms, ancient letters relied not on an impersonal, and to that extent invisible, postal service, but on friends, contacts, servants, dependents, acquaintances, travelling, perhaps, along any number of circuitous routes. Addressed to friends, to clients, patrons, colleagues, intimates, letters replicated existing networks of relationships between people, and they served to reinforce those networks. Although anchored in the specific context from which they were sent, the letters of Cicero or of Pliny fill the space of the Republic and early Empire with a web of contacts, influence, shared concerns and values, as well as of political maneuvering or resistance. Such networks could be extended by letters, with the absent author acting as broker, whether between those who would physically meet or between those who would join 'the community of the absent': 'Aulus Trebonius ... is confident that by these letters of mine he will become favoured by you' (Cicero, Ad Fam. I.3); 'Mark, my son ... greets you' (1 Peter 5.13); 'hold Irenaeus in esteem' (Eusebius, H.E. V.4.2). At the same time, imperial letters and mandates conveyed the power of the centre, exercised through delegates, over distant provinces marking out the extent of the Empire, setting boundaries or even expanding its sphere of influence. Although much outnumbered by the Greek and Latin traditions, and easily overshadowed by them, letters radiated out to or between at least some of the scattered communities of the Jewish Diaspora, both in actual practice but also in the literary imagination, such as the Jeremiah-Baruch corpus with which this paper started. ${ }^{15}$ In each of these cases letters do not simply witness to and reinforce a network; they provide the network with a defining narrative, perhaps offering a challenge to alternative narratives: Cicero's letters present him as a man always able to call on powerful friends to help others; Pliny carefully constructs his relationship with Trajan as one of friendship; ${ }^{16}$ Jeremiah lays down a challenge to Shemaiah's alternative 'unsanctioned' missive (Jer. 29.24-32); 2 Corinthians offers a composite

\footnotetext{
${ }^{14}$ On this in Ephesians see Nils Alstrup Dahl, 'The Particularity of the Pauline Epistles as a Problem in the Ancient Church', in Studies in Ephesians: Introductory Questions, Text- and Edition-critical Issues, Interpretation of Texts and Themes (David Hellholm, Vermund Blomkvist and Tord Fornberg, eds.; WUNT 131; Tübingen: Mohr Siebeck, 2000) 165-78, 170.

15 See Doering, Ancient Jewish Letters, 430-4, and above n. 2.

16 On the effect of the collection of Cicero's letters of recommendation in Ad Fam. XIII, perhaps by an editor, see Peter White, Cicero in Letters: Epistolary Relations in the Late Republic (Oxford: Oxford University Press, 2010) 46-51; on Pliny see Carlos F. Norena, 'The Social Economy of Pliny's Correspondence with Trajan', AJPhil 128 (2007) 239-77; Roy K. Gibson and Ruth Morello, Reading the Letters of Pliny the Younger: An Introduction (Cambridge: Cambridge University Press, 2012) 251-64.
} 
account of Paul's negotiations with the church; Polycrates sets out a rival narrative of eucharistic practice to that asserted by Victor of Rome (Eusebius, H.E. V.24.1-8).

It would be easy to multiply parallels among Christian letters to all of this. When 'Peter', 'through Silvanus', writes to the elect of the diaspora of Pontus, Galatia, Cappadocia, Asia and Bithynia (1 Peter 1.1; 5.12), they are being constructed not as a haphazard collection of disconnected units, aliens in relation to each other, but as a unified colonised space with its own boundaries - to internal eyes if not to those of outsiders. Ancient readers would not have studied this list of place names with a map at hand, as do modern scholars when attempting to reconstruct a messenger's journey, but as a litany of interconnected regions that dwarfed their own experience. The authors of what our text editions call 'the Martyrdom of Polycarp' exploit this further: 'the Church of God sojourning at Smyrna to the Church of God sojourning in Philomelium and to all the sojournings of the holy (catholic) church in every place' (Mart.Poly. Praef.; cf. Eusebius, H.E. IV.15.3).

The letters of Ignatius in particular illustrate this conquest of alien space, or perhaps its redefinition. Through the letters, in deep irony, we observe how Ignatius, a prisoner of the Roman Empire, forced to travel through Asia Minor and Greece en route to Rome, claims for himself the space through which he travels, turning his frog-march into a triumphal, quasi-religious, procession, marking particular points and reaching a climax in the capital city - but then, subversively, he writes to the church there, 'neither the corners of the universe nor the kingdoms of this age are of any benefit to me' (Ignatius, Rom. 6.1). ${ }^{17}$ Through his letters Ignatius welcomes delegates and urges the sending of others; in so doing he recreates these delegates as forms of letters themselves, in whom he sees, 'as if' present, the absent communities to whom he writes: 'For I have received and have with me the embodiment of your love in your bishop' (Trall. 3.2). It is difficult to read the letters of Ignatius other than as a collection; despite their individual characteristics, it is when they are read together that these letters redefine the space onto which they are mapped. ${ }^{18}$ It is for this reason that it is so difficult finally to determine the 'authenticity' of the letters, and also their relationship to a Syrian Christian by the name of Ignatius. ${ }^{19}$ This was an age when Collections of Letters became a genre in its own right, with its own

17 On Ignatius' self-presentation in terms of a procession see Alan Brent, Ignatius of Antioch and the Second Sophistic (STAC 36; Tübingen: Mohr Siebeck, 2006); on how this redefines space see Katharina Waldner, 'Ignatius' Reise von Antiochia nach Rom: Zentralität und lokale Vernetzung im christlichen Diskurs des 2. Jahrhunderts', in Hubert Cancik, Alfred Schäfer and Wolfgang Spickermann, eds., Zentralität und Religion (STAC 39; Tübingen: Mohr Siebeck, 2006) 92-121.

${ }^{18}$ It is assumed here that the Middle Recension is the earliest recoverable form of the letters. The separate history of the transmission of Romans in association with the Martyrdom of Ignatius, however that arose, might produce alternative readings of the Collection.

${ }^{19}$ See Walter Schmithals, 'Zu Ignatius von Antiochien', ZAC 13 (2009) 181-203, and the earlier discussion in the same journal 1997-1999. 
potential for experimentation and manipulation. ${ }^{20}$ Any such Collection, by definition, dissolves the bond between the individual letter and the specific places inhabited by the author and by the recipients, and in this way creates the possibility of reading them collectively as a narrative, whether as a narrative of external events or as one of the author's or the recipient's personal journey. ${ }^{21}$

Ignatius self-consciously writes in 'apostolic manner' (ćv ó $\pi 0 \sigma \tau о \lambda \iota \kappa \tilde{\omega}$ $\chi \alpha \rho \alpha \kappa \tau \tilde{\eta} \rho$ : Trall. Praef.) - an allusion to the concept of an 'apostolic letter' but also perhaps to the idea of Collection. Thus he invites us to envisage how those who received a Pauline collection might also reimagine though it a connected world, populated by witnesses to the Gospel, bound to each other: an imagined textual community. ${ }^{22}$ Uncertainties regarding the earliest ordering of the Pauline Letters, in particular the place of Romans, and additions or alterations at the textual level (Rom. 15-16; 1 Cor. 1.2; Eph. 1.1), hint at such re-imaginings. Yet these imagined communities could take different forms, as they already did in the second century: Marcion's interconnected reading discovers the Gospel and its faithful interpreters under continual threat from the forces of the Demiurge, 'the God of this world'; for the so-called 'Marcionite' Prologues, if they originated as a single Preface, carefully differentiated locally defined peoples are recalled to the true faith against the threat of infiltrators - 'the Galatians are Greeks ... the Corinthians are Achaeans'; by contrast, in the Muratorian Canon Paul's address to seven churches echoes the Apocalyptist 'writing to seven but speaking to all' (10b. 23-27). ${ }^{23}$

Looking forward, our own view of the connectedness and the spread of Christianity in the second century CE is the consequence of the impression that Eusebius creates, and that he consciously intended, in his repeated appeal to letters sent between individuals and communities in the period. ${ }^{24}$ The claim of

20 See Roy Gibson, 'On the Nature of Ancient Letter Collections', JRS 102 (2012) 56-78; Rosenmeyer, Ancient Epistolary Fictions, 193-233, on collections of pseudonymous letters; Neil and Allen, Collecting.

${ }^{21}$ See Michael Trapp, 'Biography in letters: biography and letters', in Brian McGing and Judith Mossman, eds., The Limits of Ancient Biography (Swansea: Classical Press of Wales, 2006) 335-50.

22 This is an imagined, textually-constructed, community, and not one formed around the reading of texts as in Brian Stock's influential use of the term. ${ }^{23}$ On Marcion's reading of Paul see Judith M. Lieu, Marcion and the Making of the Heretic: God and Scripture in the Second Century (Cambridge: Cambridge University Press, 2015) 234-69. On the Latin Prologues see Nils Alstrup Dahl, 'The Origin of the Earliest Prologues of the Pauline Letters', in Studies in Ephesians, 179-209; Eric W. Scherbenske, Canonizing Paul: Ancient Editorial Practice and the Corpus Paulinum (Oxford: Oxford University Press, 2013) 8593: whether or not they are Marcionite in origin is not pertinent for these purposes.

${ }^{24}$ See also David J. Devore, 'Character and Convention in the Letters of Eusebius' Ecclesiastical History', Journal of Late Antiquity 7 (2014) 223-52, who demonstrates how Eusebius uses letters to paint the good character of Christians. I am grateful to James Corke-Webster for discussion of this point. 
the anonymous author of the Letter to Diognetus, that 'Christians are spread throughout the cities of the world' (Diog. 6.4), might not have been justified by any census figures, but it was surely true when it comes to the epistolary imagination.

2. Half a conversation: social space

'Artemas, who drew up the letters of Aristotle, says that one should write a letter in the same manner as a dialogue. "For the letter is like one side of a dialogue".' (Demetrius, De Eloc. 223). ${ }^{25}$

We may well be bemused by the letter sent by Octavian, 'The all-powerful Caesar, son of the divine Julius, to the magistrates, council, and people of Ephesus, greetings. If you are well it is good; I myself am well along with the army ...' $(S E G 32,1128) .{ }^{26}$ There are, of course, many documents usually classified as letters that drop these conventional marks of personal relations the greeting, the health wish, closing farewells. But it was taken for granted that the letter should not be an exercise in oratorical declamation by a self-indulgent rhetor or literary stylist. ${ }^{27}$ Demetrius qualifies the 'half a conversation' only by admitting there is an element of careful preparation to a letter because it is 'sent as a sort of gift' (De Eloc. 224). The letter was built around a relationship, replying to something already initiated or anticipating some response, in writing or in action. As appears most effectively in letters of friendship, the letter sustains and reproduces that relationship: friendship and gifts convey or stimulate reciprocal obligations. Sometimes the other half of the conversation may survive, as in the fictional 3 Corinthians; ${ }^{28}$ on occasion we may think we can reconstruct it, as in that letter's more Pauline predecessors; more often the reader is left to complete the dialogue with their own imaginative, but easily misled, response.

The personal character of the relationship established by a letter is enshrined by the repeated 'I' (or 'we'), who variously encourages, appeals to, comforts, makes requests of, the silent 'you'. Again, there is an irony here; the letter presupposes and reinforces the separate identities and roles of 'I' and 'you', but it also seeks to overcome them, to bring them into linguistic proximity, to create a shared space: 'I never receive one of your letters without us immediately being one' (Seneca, Epist. 40). At the beginning of 1 John, 'we write to you' (1 John 1.4), but by its end

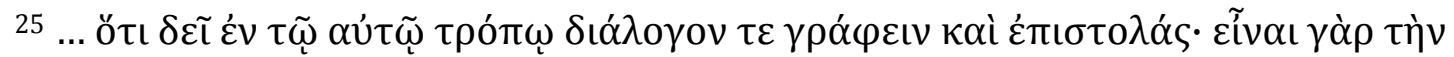

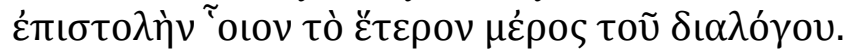

26 39-38 BCE; also available at http://insaph.kcl.ac.uk/iaph2007/iAph080031.html\#edition (accessed 14th October 2015).

27 Demetrius, De Eloc. 225; this is much repeated by letter writers, e.g. Plutarch, De Tranq. 464 (below, n. 00).

${ }^{28}$ This is not to ignore that both sides of the correspondence in 3 Corinthians are fictional: see Benjamin White, 'Reclaiming Paul? Reconfiguration as Reclamation in 3 Corinthians', JECS 17 (2009) 497-523. 
'we' share a voice: 'we have known' (1 John 5.18-20). ${ }^{29}$ Yet not all letters succeeded in this merging of identity, or even wanted to; letters can use distance to preserve independence and private space; the degree to which it was appropriate in a letter to utter rebuke or criticism that could not be said face-toface was, and is, a matter of debate, as is already negotiated by Paul and decisively developed by Augustine. ${ }^{30}$

Thus letters create a distinctive social sphere, with its own internal conventions, its own sets of relationships, its own language of relationality. They provide a space within which community beyond the immediate spatial constraints can be explored and imagined. Despite the later - perhaps early in some areas - high value given to an ascetic 'being solitary' in Christian thought, letters establish Christian existence as one that is held preeminently in relationship with others - as indeed later letters written by the monks themselves also demonstrate. ${ }^{31}$

In this light it is striking that the classic greeting formula is set in the third person, and so treats both the author and the recipient on the same plane: 'Caesar ... to the people of Ephesus'; 'The Elder to the beloved Gaius' (3 John 1).32 This may serve as a reminder that the 'you' is never the 'real you', but is one who, or which, is imagined and is shaped by the letter, whether explicitly so - ' 0 foolish Galatians', 'Called to be saints' - or in a more subtle but totalitarian way, Seneca's (probably invented) Lucilius. ${ }^{33}$ Without further correspondence there can be no way of knowing how the recipients responded to the role or the character they had been assigned; unless perhaps the survival of the letter indicates a degree of acquiescence. But this is not just to acknowledge the dangers of mirror reading or to justify straining to catch the alternative voices of the widows chastised in 1 Timothy or of the Corinthian community; it is to recognise that letters always project the recipients as they are perceived or idealised by the author.

${ }^{29}$ See Judith M. Lieu, 'Us or You? Persuasion and Identity in 1 John', JBL 127 (2008) 805-19.

30 'It is my custom to share with you all my thoughts and to warn you with those directives and examples with which I warn myself', Pliny, Epist. IV.24; cf. Cicero, De Amicit. 25.91, 'to warn and be warned is a mark of true friendship'. Ebbeler, Disciplining Christians, 7-9, argues that where Augustine was innovative was in 'his expectation that a letter of rebuke would be reciprocated'.

${ }^{31}$ Samuel Rubenson, 'Argument and Authority in Early Monastic

Correspondence', in A. Camplani and G. Filoramo, eds., Foundations of Power and Conflicts of Authority in Late Antique Monasticism (OLA 157; Leuven: Peeters, 2007) 75-87. Malcolm Choat

32 The third person and infinitive is rooted in the messenger formula, 'Thus says ...'. Ignatius regularly undermines the pattern by introducing the first person 'I

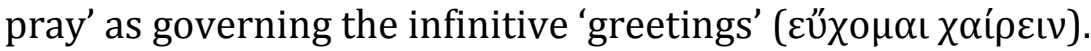

33 On Seneca and Lucilius as characters in Seneca's letters see Brad Inwood, Reading Seneca: Stoic Philosophy at Rome (Oxford: Clarendon Press, 2005) 32252. Letters between communities, while more complex, can also be understood under this rubric. 
The same is also true of the author, who is equally given a role denoted by the third person. The self-conscious young person who writes for the first time a love letter has to construct herself or himself as a fluent, passionate lover, finding a voice that would never come naturally in any unmasked face-to-face encounter. ${ }^{34}$ So, too, the letter writer creates for herself a persona: Paul, whose letters were powerful, acquires a different voice than that he would use in other settings. (Where would we be if it had been the other way around?). The confident 'Paul, apostle' needs no self-defence, even if he elaborately justifies this. But, it should be remembered, the contrast with the 'weak in presence' (see above) is itself part of the overarching self-presentation of the letter-writing

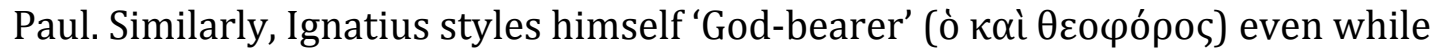
denying that he 'was someone' (Eph. Praef.; 3.1), producing a mask behind which only the imagination can peek; already, Eusebius knew of no Ignatius but the 'I' of the letters (H.E. III.36), and it is a mistake to introduce Ignatius independently of and prior to his letters. ${ }^{35}$

In understanding the writing and reading strategies involved here narrativecritical analysis of implied authors and implied audiences may have something to offer (more perhaps than they do to Gospel-analysis). But we do not have to appeal only to a contemporary methodology. The leading value of letters in rhetorical education was as an exercise in prosopopoiea (or ethopoiea). ${ }^{36}$ This then becomes exemplified in pseudonymous letters which self-consciously adopt a fabricated voice, whether of a renowned figure of the past, in the pseudonymous letters of Plato or Apollonius of Tyana, or of some more fantasyful role in the present, in those of fishermen or prostitutes. ${ }^{37}$ Yet such an exercise was only possible because there is an element of 'creating a persona', of prosopopoiea, in all letter writing.

This element of construction, if not of fictionality, which is a feature of all letters is all the more obvious when it comes to pseudonymous letters, whether or not overt. Here too, the actual recipients or first readers of such letters in some sense surely had to collude with the fiction, whether knowingly or not; although fully aware that they were not the epistolary audience, in many cases perhaps not in the epistolary location, they nonetheless presumably read the letter without embarrassment. This act of 'overhearing' or of 'reading over the shoulder' again is only a specific case of what is potential for all letters. Already as a child I was taught that it was taboo to read other people's letters; however, that is largely a modern constraint, which, particularly in an age of mistyped addresses and of the disclaimer at the foot (and not the heading) of e-mails, we are learning to treat with appropriate scepticism. A common literary device in the novels even

\footnotetext{
${ }^{34}$ Hence the need for templates both in ancient tradition (typoi epistolikoi) and as now available on the internet.

35 So also already Origen; the tradition that Ignatius was second (or third) bishop of Antioch does not reflect any independent tradition.

${ }^{36}$ Aelius Theon, Progymnsmata 115.11-22, (Michel Patillon \& Giancarlo Bolognesi, eds. (Paris: Les Belles Lettres, 1997) p. 70, n. 342 note that ethopoiea is used elsewhere).

${ }^{37}$ Rosenmeyer, Ancient Epistolary Fictions.
} 
of the $18^{\text {th }}$ and $19^{\text {th }}$ centuries (at least in English) is when a letter goes astray or falls into the wrong hands, while the anxious lover looks hastily at the plate of letters on the hallway table, hoping to remove secretly the eagerly awaited missive before someone else sees it and claims the right to hear its contents. The same is true in the ancient world; here, too, letters embedded in the story, and their misadventures, play a crucial role in novels: Chaireas writes to Callirhoe assuring her that he is alive, but through the perfidy of the slaves to whom it is entrusted the letter falls into the hands of his rival Dionysius with devastating effect (Chariton, Chaireas IV.4-5). ${ }^{38}$ Every one knew, as indeed until recent times, that letters were bound to be read by other people; they might be read by the letter carrier, or by someone into whose hands they fell by mistake; they might be intentionally read aloud in the company of family, friends, or servants, or shared with those who were explicitly sent closing greetings; they might be discussed with other acquaintances - whether by the sender or by the recipient, intended or not. ${ }^{39}$ The line should not be drawn too firmly separating private or personal from public; at the same time the extended audience is not an indiscriminate one (at least not in intention) but is contained and controlled, perhaps explicitly so, by the predefined, even if porous, boundaries of the constructed community of reception.

Again, to some extent this may serve as a model or microcosm for the hermeneutical moves that made it possible for much later readers who defined themselves as Christians to re-read these letters; through them they were able to imagine themselves in multiple relationships with the earliest readers, but also with other contemporary readers, as sisters, brothers, heirs. Some simply appended their 'Amens' to the text, while other scribes more boldly added comments or prayers in their own names. Even the earliest commentators negotiated, as do modern scholars, the perplexities of 'one who considers Paul's letters with more curiosity, as though Christ is speaking in him' (Origen, Comm. in Rom. X.39).

\section{A mirror of the soul: interior space}

'One writes a letter as an image of one's own soul' (Demetrius, De Eloc. 227). ${ }^{40}$

The convention that the letter revealed the person as she really was, was merely an extension of the fundamental principle that all verbal self-expression reveals the character of the individual, their ethos: 'Just as is someone's speech so is their life' (Talis hominibus fuit oratio qualis vita: Seneca, Epist. 114.1). ${ }^{41}$ The

\footnotetext{
38 See Thomas E. Jenkins, Intercepted Letters: Epistolarity and Narrative in Greek and Roman Literature (Lanham: Lexington, 2006).

${ }^{39}$ Lucilius asks Seneca not to discuss his affairs with the 'friend' who has brought the letter (Seneca, Epist. 3), while Seneca sends Lucilius a copy of a letter of condolence he wrote to Marullus (Epist. 99). Cicero, Ad Att. XI.9.2, opened a letter addressed to someone else because he thought there might be something incriminating therein, and discussed his action with Atticus.

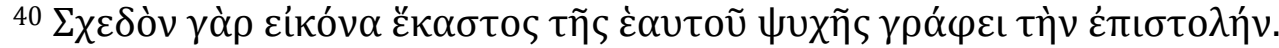

${ }^{41}$ Seneca ascribes the saying to the Greeks, while Cicero (Tusc.Disp. V.16.47)

attributes it to Socrates. Philo uses the epigram to describe Moses' commitment
} 
framework of the personal relationship, and the consequent self-consciously relaxed style, made this supremely true of the letter: 'I see you entirely in your letters' (Te totum vidi in tuis epistulis: Cicero, Ad Fam. XVI.16.2). Polycarp's letter

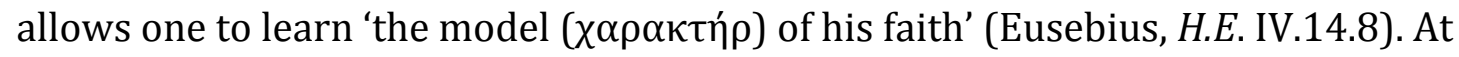
first glance there is a contradiction between all that has been said above about the prosopopoieic nature of the letter and this convention of its self-revealing character. It is a contradiction that may find some resolution to the extent that the person or self is seen as 'work in progress'. Michel Foucault made good use of letters in his argument that in the early Empire there was a turn to the self and to a concern with self-fashioning; numerous studies have followed of how Pliny or Seneca 'fashion' themselves not only through their letters, but also through the collection and the publication of these. ${ }^{42}$

Recent scholarly analysis of 'the individual' or of 'the self' in the thought of this period, and particularly within religious thought and practice, still struggles to articulate the implications of the philosophical encouragement to attend to one self without viewing it through the lens of a post-Enlightenment selfinterrogation by 'I'. 43 'Retreat into yourself as far as you are able' (Recede in te quantum potes: Seneca, Epist. 7.8). Here, perhaps, the letter-framework of intimacy-in-relationship is instructive: the letter provided an appropriate context for self-reflection while at the same time encouraging someone else to do the same, in dialogue, regardless of whether or not that dialogue is fictional. ${ }^{44}$ Although Galen's recently discovered work 'On Avoiding Distress' deals with themes common in moral philosophical treatises, its explicit introduction as a letter in response to an epistolary request as to 'what training, arguments, or doctrines prepared me never to be distressed' provides a natural framework for its deeply autobiographical yet consciously exemplary character. ${ }^{45}$ The Martyrdom of Polycarp similarly represents itself as a response to a request for information from those addressed but assumes they will learn from it and share

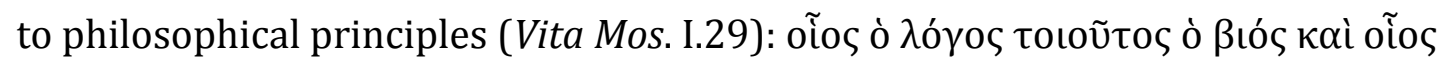

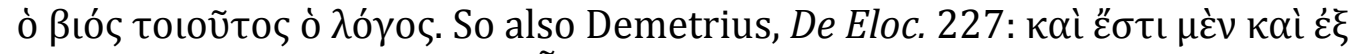

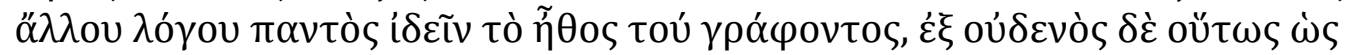
$\varepsilon \dot{\pi} \iota \sigma \tau о \lambda \tilde{\eta} s$.

42 See above n. 16 and also Inwood, Reading Seneca, 322-52.

43 See the brief discussion by Johannes Zachhuber and Alexis Torrance, 'Introduction', in eidem, eds., Individuality in Late Antiquity (Farnham: Ashgate, 2014) 1-9; also Patricia Cox Miller, 'Shifting Selves in Late Antiquity', in David Brakke, Michael Satlow, Steven Weitzmann, eds., Religion and the Self in Antiquity (Bloomington, Ind.: Indiana University Press, 2005) 15-39.

${ }^{44}$ See Kathy Eden, 'A Rhetoric of Intimacy in Antiquity', in The Renaissance Rediscovery of Intimacy (Chicago: University of Chicago, 2012) 11-48; Amanda Wilcox, The Gift of Correspondence in Classical Rome: Friendship in Cicero's Ad Familiares and Seneca's Moral Epistles (Madiscon, Wis.: University of Wisconsin Press, 2012) 8-9, 121-3.

45 See Clare K. Rothschild and Trevor W. Thompson, eds., Galen's De indolentia (STAC 88; Tübingen: Mohr Siebeck, 2014). So, also, Plutarch's De Tranquilitate is in the form of a letter to a certain Paccius and consciously eschews stylistic elegance in favour of practical usefulness. 
in glorifying God (Mart.Poly. 20). ${ }^{46}$ Seneca, the arch-exponent of such a genre, says to Lucilius, 'You are my work' (Epist. 34.2), and he would have many Christian successors for whom the letter articulated the dual demand for pastoral responsibility towards others and personal obligation for oneself. Like Paul, Dionysius of Corinth feeds communities or individuals with 'nourishing food' by letter (Eusebius, H.E. IV.23; 1 Cor. 3.1). The solitary, reflective or idiosyncratic dimensions, on the one hand, and the relational ones, on the other, of such processes are not easily untwined. At the same time, the rhetoric and vocabulary adopted to create intimacy may leave us uncomfortable, and serve as a reminder that any construction or expression of intimacy, and particularly of epistolary intimacy, is culturally specific: Marcus Aurelius writes to Fronto, 'Should I not burn with love for you, who have written to me as you have', and modern scholars speculate about the nature of that love. ${ }^{47}$

A letter was also the appropriate medium for expressing grief or distress, both personal and when sending condolences to another, even, perhaps especially, where such emotions seemed to be in tension with the philosophical ideals of self-control. ${ }^{48}$ The intimacy that made this possible could be signalled within the letter by the epithets used in address, by the adoption of more colloquial language, or by other forms of code-switching. More mundanely, letters often anticipate or provoke express emotional responses. To some extent it is the very fact of distance presupposed by the letter that makes intimacy or the personal in such conditions possible, where face-to face contacts would be culturally more difficult to negotiate; in turn awareness of this fact intensifies the emotional affect of the letter as it is read. Readers are enabled to internalise the experiences articulated in and negotiated by the letter, particularly as they repeatedly re-hear or re-read it. As new readers encounter the letter(s), they too become intimates. Because it took the form of a letter, those who received the account of the persecution at Lugdunum and Vienne, both initially and subsequently, were offered little choice but to accept the 'gift' of the perception of those who sent it, and to share the grief, anxiety and hope at the unfolding of suffering and faithful resilience, not least because as addressees they are described as 'brethren sharing the same faith and hope of redemption as us' (Eusebius, $H E$ V.1.1-2.8). A scribe who copied the letter known as 'the Martyrdom of Polycarp' adds his own express ('I, Pionius') hope that as a result of these labours Christ might gather him too with his elect (i.e. the martyrs) into the heavenly Kingdom, while the closing 'Amen', and perhaps the doxology, was probably added by subsequent readers (Mart.Poly. 22.3).

Yet these are but extensions of what Paul endeavours to achieve when he asserts that the Philippian believers do indeed 'have the same contest as you saw in me,

\footnotetext{
46 This is missing from the version in Eusebius, perhaps because the letter has a new extended function in the context he gives it.

47 C. R. Haines, trsl., Marcus Cornelius Fronto (LCL; Cambridge, MA: Heinemann, 1962 [1912]) 18-21.

48 See Cicero, Ad Fam. IV.6 to Servius Sulpicius: 'How much you could have helped me if present by comforting and equally sharing in grief I can easily understand from the degree to which I was helped by your letters when read'.
} 


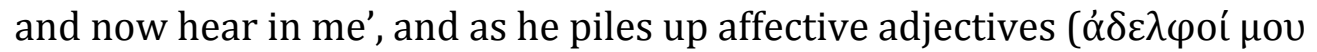

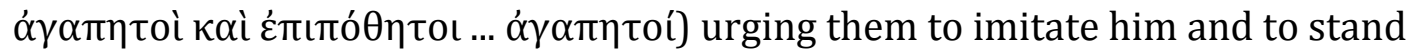
firm (Philipp. 1.30; 3.17-4.1). ${ }^{49}$ In letters, an author can explore the direction of the will and the exercise of the emotions through an appeal to personal experience as well as through the example of others. This is even more the case if conventional attitudes are being challenged, and if emotional norms or networks are being redefined.

When Galen grudgingly commends the contempt for death shown by Christians and their pursuit of virtue but decries their failure to rely on reason in so doing, ${ }^{50}$ perhaps he indirectly bears witness to the transformation of what here has been called 'interior space', most effectively through letters.

To draw this together:

It should be clear that it is not being argued here that all early Christian letters achieve these goals, nor even that any particular letter achieves them all, nor that letters alone achieved them. Moreover, in none of this can one claim any form of uniqueness for early Christianity or for its letters. ${ }^{51}$ More than a century of research has shown that while it may be debated as to what are the most appropriate points for comparison, Christians did write letters in much the same ways as did everyone else. ${ }^{22}$ Yet it is also true that the usefulness of letters was such that it was no accident that under the Christian pen the art was to achieve such a zenith in later centuries. Here they were indeed building on the potentialities established in the earliest Christian centuries.

We have started with epistolary theory, and the exercise and its findings therefore might sound like yet another isolation of literary strategies - textual constructs - independent of social practice. This has indeed been the danger of some recent explorations of early Christian identity-making, as a consequence of their proper emphasis that textual rhetoric cannot be taken as straightforwardly

${ }^{49}$ See Hans Dieter Betz, 'On the Question of Literary Genre', in Studies in Paul's Letter to the Philippians (WUNT 343; Tübingen: Mohr Siebeck, 2015) 133-54. On the relationship between Philippians and the Martyrdom of Polycarp see Jane McLarty, 'The Function of the Letter Form in Christian Martyrdom Accounts', in Owen Hodkinson, Patricia A. Rosenmeyer, Evelien Bracke, eds., Epistolary Narratives in Ancient Greek Literature (Mnem.S 359; Leiden: Brill, 2013) 37185.

50 R. Walzer, Galen on Jews and Christians (London: Oxford University Press, 1949) 15-16.

${ }^{51}$ For Epicurean letters as filling some of these goals see Clarence E. Glad, Paul and Philodemus: Adapatability in Epicurean and Early Christian Psychagogy (NT.S 81; Leiden: Brill, 1995) 175-81.

52 Christoph Markschies, 'Schreiben Christen andere Briefe als Heiden: zur brieflichen Kommunikation in der kaiserzeitlichen Antike', in Ulrich Peter and Stephan J. Seidlmayer, eds., Mediengesellschaft Antike? Information und Kommunikation von alten Ägypten bis Byzanz (Berlin: Akademie Verlag, 2006) 113-30. 
descriptive of social actuality. But letters offer a framework for exploring how the textual and the social intersect. Letters are to do with performance; they are to do with ritual. Think of the etiquette of the thank you letter, no doubt different in Amsterdam than in Sydney or Heidelberg or Chicago - or in ancient Rome the note of condolence, the careful language of invitation - all of which ritualise relationships. ${ }^{53}$ This was certainly the case in the ancient world, in the practices of writing, sending, receiving, responding. It is here that what may sound like timeless truisms as discussed here - distance, relationality, intimacy - in fact are articulated in highly distinctive ways in different cultural contexts; they are, as I have tried to show, cultural strategies. Such practices also remind us of the materiality of the letter. Demetrius' description of the letter as a gift removes it from the purely intellectual sphere; often letters accompanied or solicited gifts, whether of goods or of benefits, an expectation Seneca parodies as he adds the gift of a wise saying to his initial letters to Lucilius. Writing, carrying, sending, recording, reading, copying, preserving, collecting, ordering, all involved material cultural practices. These bring us further into the world shared by a broader spectrum of society than that inhabited only by those who had the skills or means to write. All of this is not, of course, only true of letters - once again the letter acts as a cultural symbol for considering other socially-defined practices of writing and reception.

Yet the materiality of letters also has its own intrinsic power, perhaps lost with the modern e-mail, and in no way diminished by the oral tasks of the letter carrier or messenger. Seneca prefers a letter to a picture because it offers the hand of a friend impressed on the letter' (Epist. 40.1). Just like a bundle of loveletters tied with a ribbon, the letter almost embodies the affective dimensions of its contents, even beyond those whom it initially bound together. The letter quoted earlier from Octavian to Ephesus was inscribed some two or three hundred years later on the walls of the city of Aphrodisias, which had hoped through it to recover stolen loot. ${ }^{54}$ It is possible even now at the Kunsthistorisches Museum in Vienna to stand under the protection of the correspondence between Abgar and Jesus inscribed on the underside of a door jamb from Ephesus, impossible to read without straining neck and eyes (I.Eph. 46). ${ }^{55}$ That fictional exchange of letters was over centuries one of the most popular Christian texts after the Gospels, and it was its physical reproduction that was treasured.

Not all letters can boast quite as many readers as those have had. Yet fundamental to all that that has been explored here is that the effective power of the letter lies in its insistent address to, its creation of a conversation with, its

\footnotetext{
53 See Ian H. Henderson, 'Early Christianity, Textual Representation and Ritual Extension', in Dorothea Elm von der Osten, Jörg Rüpke, Katharina Waldner, eds., Texte als Medium und Reflexion von Religion in römischen Reich (Stuttgart: Franz Steiner, 2006) 81-100.

54 See above n. 26.

55 See Derek Krueger, Writing Holiness: The Practice of Authorship in the Early Christian East (Philadelphia, PA: University of Pennsylvania Press, 2004) 149-56 on the dynamics and subsequent development of the Abgar traditions.
} 
invitation into multiple relationships to, one reader, at least, and, most of all, in an expectation of response, and hence in its 'conjuring up' of a continuing community. It is as a consequence of this effective power that, even while drawing on and replicating long-established conventions, letters provided a natural medium for the new discursive practices that were to create the Christian world, and so enable us to explore the contours of that world. More broadly, letters exemplify how Christians were both part of contemporary society and yet shaped an alternative reality through what were shared resources. ${ }^{56}$

56 Some of the research for this paper was undertaken during three months spent at the Theologische Fakultät, Humboldt Universität zu Berlin, with the support of the Alexander von Humboldt Stiftung. I am grateful for the hospitality of colleagues and for the support of the Foundation. 